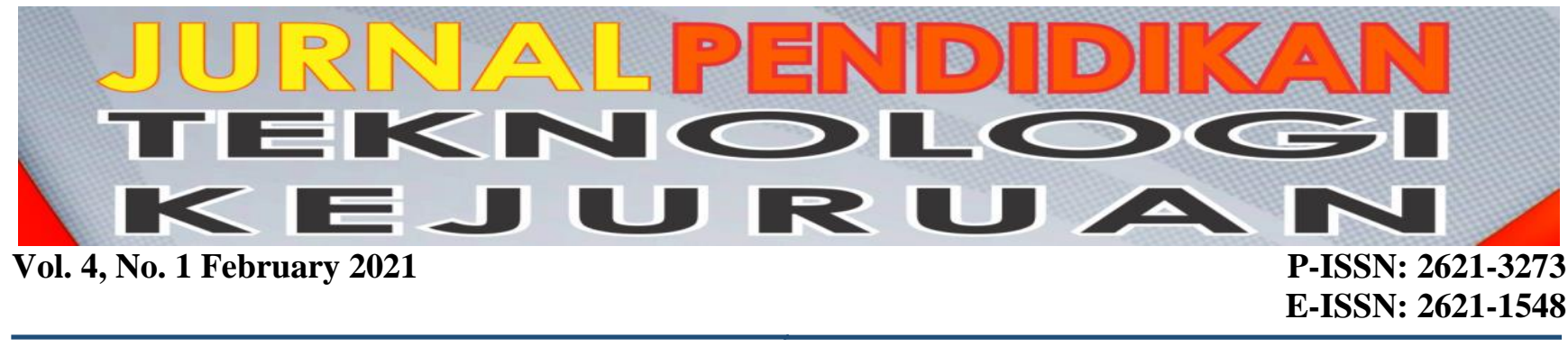

\title{
Preliminary Study of Solid Waste Treatment of Padang Beach Tourism Area
}

\author{
Rizki Aziz ${ }^{*}$, Gloria Poppy Adfuza ${ }^{2}$ and Yaumal Arbi ${ }^{3}$ \\ ${ }^{1,2}$ Faculty of Engineering, Universitas Andalas, Indonesia \\ ${ }^{3}$ Faculty of Engineering, Universitas Negeri Padang, Indonesia \\ *Corresponding author, e-mail: rizkiaziz@eng.unand.ac.id
}

\begin{abstract}
The Padang City Government through Regional Regulation Number 550 of 2014 concerning Waste-Free Areas has placed Padang Beach as one of the areas in the city that must be free of waste. The purpose of this study was to conduct a preliminary study of waste processing in the Padang Beach tourist area. The method used is by analyzing waste generation, composition, and recycling potential. This needs to be done because it can provide recommendations for the right processing system to be applied in the Padang Beach tourist area. The results showed that the daily waste produced was $18,648 \mathrm{~L}$, the components of the waste were dominated by food waste $84.215 \%$, plastic $9.254 \%$, paper $2.087 \%$, and non-metal iron $1.945 \%$. The potential for recycling the waste is food waste $\mathbf{9 1 . 7 3 2 \%}$, plastic $\mathbf{8 8 . 0 7 4 \%}$, metal $\mathbf{7 8 . 9 4 7 \%}$ and glass $\mathbf{7 5 . 7 5 8 \%}$. The recommendations given are that waste with economic value of plastic, paper, and metal is collected and sold to third parties, biodegradable waste such as food scraps and yard waste should be composted, while other possible waste can be processed into compost. produce handicrafts such as clam shells, coconut shells, and sachet packaging must be collected and managed, all maintenance activities can be carried out at recycling centers located in tourist areas.
\end{abstract}

Keyword： Solid waste, Generation, Composition, Recycle potential, Padang Beach

\section{INTRODUCTION}

Padang is the capital city of West Sumatra province has famous for its tourist attraction, mostly related to its culinary and beauty of nature primary for the beach. The number of visitors to Padang Beach in 2016 was 3,771,823 people, and in 2017 it was $4,400,908$ people, its mean increased $14.30 \%$ for a year (Dinas Pariwisata Kota Padang, 2017), it is predicted continue to increase since Padang Beach is being beautified so more visitors will come and enjoy the view and the culinary. More visitors and facilities mean more waste will be produced and need to manage.

Government of Padang City by Major Regulation Number 550 the year 2014 about Free Waste Area has put Padang Beach as one of the areas in the city should be freed from waste, yet it is not happening. The tourist and street vendors throw their waste arbitrarily. Padang Beach is included in RIPPAR (Master plan of tourism development) as mentioned in City Regulation Number 3 the year 2014, state that management of solid waste as the element to succeed the tourism development beside the development of infrastructures and tourist attractions.
Meanwhile, Indonesian Constitution number 18 the year 2008 about solid waste management has mandated that solid waste management in Indonesia should be practice sustainable solid waste management. Sustainable solid waste management divided into the effort of waste reduction and waste handling, which include waste processing as the primary system to reduce waste transported into the disposal site. Indonesian Government Regulation number 81 the year 2012 emphasized the role of tourism area managerial should practice and provide infrastructures for solid waste management of tourism area.

Based on the observation of the existing condition of solid waste management practices, some problems presence, and improper management system still practiced. In order to develop a better system, the primary data of solid waste is needed to measure and analyze. The method, system, and facilities needed for solid waste reduction and handling will depend on the data of solid waste generation, composition, and characteristic (Damanhuri E and Padmi T, 2016). 
This research aims to measure and analyze solid waste generation, composition, and recycling potentials of Padang Beach tourism area, as well as to analyze the current condition of solid waste management practice, and to recommend the appropriate treatment system of future solid waste management (Arbulú I et all, 2016).

Study on tourism waste has develop since last fifteen years located in various region in Asia and Europe (Bhat RA et all, 2014) (Zorpas AA et all, 2015) (Hoang MG et all, 2017) (Giurea R, Precazzini I, 2018) especially Indonesia it is located in West Kalimantan (Naltaru M et all, 2014), Bali, Yogyakarta, Central Java, and West Sumatra . The study reported the quantity of solid waste generated, and some of them reported the composition and recycling potential (Wijaya IW dan Trihadiningrum $\mathrm{Y}, 2014)$.

Waste generation is the quantity or the amount of waste produced by people each day. The waste generation connects to these elements. Waste composition is the depiction of each component conceived in waste. The composition usually found in weight percentage (Damanhuri E and Padmi T, 2016). Recycling potential configures the percentage of each waste type able to recycle(Akbari R, 2018).The purpose of this study was to conduct a preliminary study of waste processing in the Padang Beach tourist area.

\section{METHOD}

This study has three main steps they are;

a. Literature reviews related to journals, reports, and other related documents to this study.

b. Data collection includes current solid waste management practices by observation and interview with staff of related agencies related, measurement and analysis of solid waste generation, composition, and recycling potential conducted in the location for eight sequentially days.

c. Recommendation for solid waste treatment system considered applicable technology and community participation and economic values of waste.

\section{RESULT}

\section{Solid Waste Generation}

Solid waste in Padang Beach generated from some facilities provided at the area, and it comes from various sources such as restaurant/café, street vendors, worship place, hotel, clothes seller, fish hawkers, estuary, shore, and pedestrian and park. The amount of waste generated measured for eight sequentially days, after analysis and considering the number of visitors, traders, and also area of the sources, the average of the generation presented in Table 1.

Table 1 Solid waste generation of Padang Beach

\begin{tabular}{lll}
\hline \multirow{2}{*}{ Facility } & Generation & \\
& $\mathrm{Kg} /$ day & $\mathrm{L} /$ day \\
\hline Restaurant/ Cafe & 268.176 & $5,270.270$ \\
Street vendors & 586.522 & $11,434.398$ \\
Worship place & 13.193 & 301.483 \\
Hotel & 6.468 & 110.921 \\
Clothes seller & 2.315 & 242.575 \\
Fish hawkers & 40.248 & 775.333 \\
Estuary & 6.582 & 50.939 \\
Shore & 10.587 & 179.551 \\
Pedestrian and Park & 11.373 & 282.749 \\
Total & 945.464 & 18.648 .218 \\
\hline
\end{tabular}

Table 1 showed the highest contributor for the waste is street vendors as $586.522 \mathrm{~kg} /$ day or $11,434.398$ L/day or as $61-62 \%$ of total waste generated, followed by restaurant/café as $268.176 \mathrm{Kg}$ /day or $5,270.270$ L/day or $28 \%$ of total waste generated. The smallest contributor is clothes seller as $2.315 \mathrm{~kg} /$ day and estuary as 50.939 L/day.

\section{Solid Waste Composition}

Padang Beach generated waste from various sources with various compositions. The collected samples were measured, analyzed, and presented in Figure 1. The highest composition is food waste as $84,211 \%$ of total waste produced, followed by plastic as $9.254 \%$, paper as $2.087 \%$ and non-metal ferrous at $1.945 \%$. Food waste produced by culinary facilities such as restaurant/café and street vendors that dominate Padang Beach facilities. The least composition is textile for $0,056 \%$.

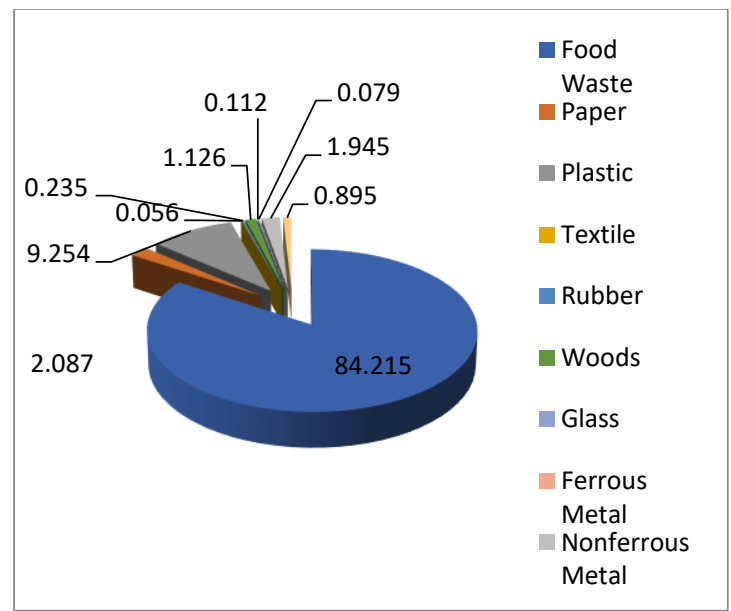

Fig.1 Solid waste composition of Padang Beach 


\section{Recycling Potential}

Recycling potential of solid waste is determined by waste component that recyclable. Waste recycling potential showed in Table 2.

Table 2 Recycling potential of Padang Beach's waste

\begin{tabular}{lll}
\hline Component & \% Recyclable & \% Residue \\
\hline Food waste & 91.732 & 8,268 \\
Plastic & 88.074 & 11,926 \\
Paper & 28.604 & 71,396 \\
Metals & 78.947 & 21,053 \\
Glass & 75.758 & 24,242 \\
Woods & 20.115 & 79,885 \\
\hline
\end{tabular}

Table 2 showed the wastes that have high recycling potential includes food waste, plastic, metals, and glass as $91.732 \%, 88.074 \%, 78.947 \%, 75.758 \%$ respectively. Meanwhile, paper and woods have potential recycling percentage less than $30 \%$.

Less of recyclable paper caused by the mixed of waste on the storage which is degraded the quality of the paper and also because of tissue paper from culinary sources; meanwhile woods waste mostly come from home/shop renovation where the woods already painted and could not be recycled easily. For other wastes like textile, rubber, and other wastes has no recycling potential.

\section{DISCUSSION}

\section{Current Solid Waste Management Practices}

Current practices of solid waste management in Padang Beach as follows. The level of service in Padang Beach Tourism Area is $47 \%$. The scale of waste management in Padang Beach Tourism Area is the city scale. Waste is not sorted at the source then placed into individual containers such as trash bags, trash bin, rattan and communal containers in the form of plastic bin, steel bin with 2 and 3 sorting types of garbage and containers. Waste is collected using a collector in the form of a $1.5 \mathrm{~m} 3$ motorized tricycle as many as four units in a mixed state. Waste moves from communal containers to containers with motorized tricycle tools to transport vehicles in the form of four units of dump trucks. No waste processing or treatment applies. Waste is transported to landfill without any processing.

\section{Recommendation on Solid Waste Treatment}

The treatment of waste in Padang Beach Tourist Area after collection is processing at the recycling center located near Padang Beach Tourist Area. In order to develop the function, following steps needed to do: (a) re-operate the nearby recycling center which has stop operation for couples years; (b) providing facilities and infrastructure for storage and sorting wastes of Padang Beach Tourism Area.

In addition, waste processing considers on wastes composition. The following is the processing options to do on solid waste management system:

1. Food waste that mostly generated from culinary facilities such as restaurants/cafes and street vendors. Options for treatment: (a) food waste and yard waste treated with the composting method. This option choose since the amount of food waste, and yard waste is not too large when compared to the waste of young coconut and shellfish, the method considered appropriate is the takakura method; (b) waste from coconut shells and shellfish processed for recycling. Recycle process for young coconut waste by chopping and processing it into recycled products such as palm brooms or other handicrafts. Meanwhile, recycling processing for shellfish waste is making shellfish flour for cement mixture [19].

2. Plastic waste treated to produce plastic ore and recycle materials. Plastic ore is processed mainly for plastic bottles and cups. The plastic ore can be sold to the third party. Meanwhile, the recycling process that can be carried out on plastic waste is to make packaging waste into handmade goods.

3. Paper, glass, metal, and woods can be treated through sorting and packing. Re-sorting of waste components is carried out to separate waste that still has the selling value and not worth selling. After being sorted, the waste that is worth selling is then collected and packaged for sale to collectors or artisans.

4. Rubber, textile, and other wastes directly transported into the landfill site.

\section{CONCLUSION}

By the study of the characteristic of solid waste of tourist area of Padang Beach, it concluded that solid waste generation is $18.648 \mathrm{~L} /$ day with dominant components are food waste $84.215 \%$, plastic $9.254 \%$, paper $2.087 \%$, and non-metal ferrous $1.945 \%$. The potency of recycling of the waste was food waste $91.732 \%$, plastic $88.074 \%$, metals $78.947 \%$ and glass $75.758 \%$.

By this study it is recommended that waste that has economic value such as plastic, paper, and metal should be collected and sell to the third party, biodegradable waste such as food waste and yard waste should be composted, while others waste that has potency to produce handy craft such as seashell, 
coconut shell, and sachet packaging should be collected and processed, all treatment activities can be done at the recycling center that located in the tourist area.

\section{REFERENCES}

Dinas Pariwisata Kota Padang, 2017. Laporan Tahunan Kepariwisataan Kota Padang.

Surat Keputusan Walikota Padang No. 550 Tahun 2014 tentang Kawasan Bebas Sampah.

Peraturan Daerah Kota Padang No. 3 Tahun 2014 tentang Rencana Induk Pembanguan Pariwisata Kota Padang

Undang Undang Republik Indonesia No. 18 Tahun 2008 tentang Pengelolaan Sampah

Peraturan Pemerintah RI No. 81 Tahun 2012 tentang Pengelolaan Sampah Rumah Tangga dan Sampah Sejenis Sampah Rumah Tangga

Damanhuri E and Padmi T, Pengelolaan Sampah Terpadu, Penerbit ITB: Bandung, 2016

Bhat RA, Nazir R, Ashraf S, Ali M., Bandh SA, and Kamili AN 2014 Waste Manage Res. 32 165- 169.

Zorpas AA, Irene Voukkali I, and Loizia P 2015 Desalin Water Treat. 56 1141-1149.

Arbulú I, Lozano J, Rey-Maquieira J 2016 Waste Manage. $51252-258$

Hoang MG, Fujiwara T, and Pham Phu ST 2017 Journal of JSCE. 5 123-132

Giurea R, Precazzini I, Ragazzi M, Achim MI, Cioca LJ, Conti F, Torretta V, and Rada EC 2018 Resources. 7 $1-12$

Naltaru M, Purmaini R, dan Irsan R 2014 Perencanaan Sistem Pengelolaan Sampah di Kawasan Wisata Bukit Kelam Kabupaten Sintang. Undergraduate Thesis. Universitas Tanjungpura: Pontianak

Wijaya IW, dan Trihadiningrum Y 2014 Strategi Penanganan Sampah di Objek Wisata Eks Pelabuhan Buleleng, Bali. Undergraduate Thesis. Institut Teknologi Sepuluh Nopember: Surabaya

Akbari R, Analisis Timbulan dan Komposisi Sampah di Kawasan Bhumi Merapi dan Stonehenge Kaliurang, Sleman, D.I. Yogyakarta. Tugas Akhir. Jurusan Teknik Lingkungan, Universitas Islam Indonesia. 2018

Oktiasari R, Evaluasi Pengelolaan Sampah Wisata Gunungpring Kecamatan Muntilan Kabupaten Magelang Jawa Tengah Dengan Metode Zero Waste
Index . Tugas Akhir. Jurusan Teknik Lingkungan, Universitas Islam Indonesia. 2018

R Aziz and Mira 2019 IOP Conf. Ser.: Mater. Sci. Eng. 602 012059

Jefri dan Aziz. 2018. Studi Potensi Daur Ulang Sampah Kawasan Wisata Taman Marga Satwa dan Budaya Kinantan (TMSBK) dan Kawasan Wisata Taman Panorama dan Lobang Jepang (TPLJ) di Kota Bukittinggi. 5th ACE Conference. Padang

Aziz and Jefri, 2019, Improvement of Solid Waste Management System of Tourism Area in Bukittinggi City in Supporting The Implementation of Sustainable Tourism. Proceeding of Tourism Development Center International Conference, October 2019, Bukittinggi, 
